\title{
COMBINATION OF CONVENTIONAL AND IN-SILICO APPROACH FOR IDENTIFYING AN INDUSTRIALLY IMPORTANT ISOLATE OF AEROMONAS
}

\author{
${ }^{1}$ Thungri Ghoshal, ${ }^{1}$ Sourav Ghosh, ${ }^{1}$ Amrita Saha, \\ ${ }^{1}$ Nabanita Haldar, ${ }^{2}$ Ashoke Ranjan Thakur and ${ }^{1}$ Shaon Ray Chaudhuri \\ ${ }^{1}$ Department of Biotechnology, West Bengal University of Technology, \\ BF-142, Sector 1, Salt Lake, Kolkata-700064, West Bengal, India \\ ${ }^{2}$ Techno India University, Salt Lake, Kolkata-700091, West Bengal, India
}

Received 2014-02-14; Revised 2014-02-17; Accepted 2014-02-26

\begin{abstract}
Ammonia is required for various commercial applications while its production by standard process is immensely energy intense. Dairy industry on the other hand produces huge volume of effluent needing treatment before discharge. This study aims at developing an eco-friendly microbial approach for conversion of dairy industry effluent into ammonia under atmospheric pressure and $37^{\circ} \mathrm{C}$ temperature at laboratory scale. Thus the need for huge energy for ammonia production would be avoided. Moreover the dairy effluent would generate revenue while getting treated. This study is also an attempt to develop a bioinformatics approach for strain identification. Standard cultivation techniques and in-silico approach of analysis of draft genome was undertaken to decipher the identity of this industrially important strain. Aeromonas sp. MCC 2167 (isolated from active dairy sludge) was capable of treating un-amended dairy effluent with $6 \%$ inoculum while producing ammonia as by product at a 11 folds higher rate than the modified Habers Process. Though the strain showed maximum identity with Aeromonas hydrophila, there were certain differences in terms of substrate utilization. Majority of the contigs showed identity with Aeromonas hydrophila, however there was significant difference among the two strains in terms of intergenomic distance (genome to genome distance calculator from DSMZ), inversion and frame shift (dot plot analysis) as well as genome rearrangement (MAUVE analysis). As per the rapid annotation using subsystem technology analysis $53 \%$ of the contigs belong to the subsystem category while the remaining $47 \%$ do not match with existing sequences in the database. The above finding proposes bioinformatics validation of the wetlab based data pointing towards this industrially important strain to be a novel isolate of Aeromonas sp. This would lead to an energy efficient economically viable alternative for ammonia production while treating large bulk of effluent generated from dairy industry that needs to be treated before being discharged.
\end{abstract}

Keywords: Ammonia, Dairy Effluent, Bioremediation, Aeromonas Hydrophila, Nitrate

\section{INTRODUCTION}

The thriving Indian dairy industry is profusely multiplying its central processing plants to meet the growing demands of marketing fluid milk or it's processed by product. Typically, dairy effluent is generated from manufacturing processes, utilities and service sections. Dairy effluent with high organic matter results in high Biological Oxygen Demand (BOD) and Chemical Oxygen Demand (COD) overloading the local sewage treatment plants. Their discharge in the environment would result in depletion of the dissolved oxygen due to the oxidative microbial action, harming the aquatic inhabitants. High nitrogen and phosphorous content in dairy waste and its accumulation in the water bodies may cause the prominent problems of Corresponding Authors: Shaon Ray Chaudhuri, Department of Biotechnology, West Bengal University of Technology, BF-142, Sector 1, Salt Lake, Kolkata-700064, West Bengal, India 
eutrophication. Complications in the dairy waste treatment arise due to marked variation of hourly, daily and seasonal flow rate of the dairy effluent. Thus, exhaustive efforts have been made on the physicochemical and biological treatment processes including constructed wetlands to control the incoherent problem of dairy waste treatment and discharge of the post-treated dairy waste within the environmental permissible limits of the interfering parameters. Agricultural reuse of pretreated cheese whey water, being a rich source of biodegradable organic matter has also been tested for plants. However its high salinity content calls for dilution of the pre-treated cheese whey water as per the plant requirement (Bhadouria and Sai, 2011; Carvalho et al., 2013; Najafpour et al., 2008; Maghsoodi et al., 2007).

Apart from its treatment, dairy effluent has also been used in formulating commercial by-products, such as the generation of hydrogen and biogas using cheese whey powder as the substrate. The process recovered $70 \%$ of the energy from the substrate (Cota-Navarro et al., 2011). $64 \%$ bio-methanation has also been reported by anaerobic digestion of salty cheese whey with poultry/cattle dung (Patel and Madamwar, 1996). Studies also report the production of electricity while purifying dairy waste water. Hydrogen generated as water electrolysis byproduct can be used in a fuel cell to supply power to the system (Egner and Karos, 2013). However the production of ammonia as a by-product of the biological treatment of dairy effluent has been sparsely discussed. Ammonia, an essential naturally occurring product is contained in all life forms. Living beings can take up nitrogen mostly in the form of nitrate and ammonia. It is present in 0.01-0.05 ppm concentrations in air and commonly found in rain water (6 ppm) as well as soil (upto 5 ppm). Ammonia is vitally used in agriculture and is also varyingly essential in the food and beverage industry. The conventional Haber-Bosch method for ammonia production is a very energy intensive process. It operates at an absolute pressure ranging from $870-2,600 \mathrm{psi}$ and a temperature of $300-550^{\circ} \mathrm{C}$ using iron catalyst (Schauernheim, 2006; Ertl, 1983). Ammonia production has also been reported by bacterial genetic manipulation of nitrogenase and key glutamate forming enzymes resulting in mutants excreting fixed $\mathrm{N}_{2}$ as $\mathrm{NH}_{4}^{+}$(Shanmugamand and Valentine, 1975). Ruminal waste has also been used to produce ammonia by inoculating bacterial strain in a semicontinuous culture using trypticase, lactate and xylose as the energy and nitrogen source in the enrichment (Russell et al., 1988).

This strain is of immense commercial impact in terms of ammonia production from un-amended dairy effluent under ambient pressure. It shows similarity with Aeromonas sp. at the draft genome level (RayChaudhuri et al., 2013) yet there seems to be certain striking difference at the physiologic level. Thus the present study is an attempt to adopt insilico approach for bacterial identification using draft genome analysis. The present study aimed at the following: (1) Optimizing the inoculum for ammonia production from un-amended sweet shop effluent, (2) Testing the efficiency of ammonia production as compared to the modified chemical process (Marnellos and Stoukides, 1998) and (3) Revealing the novelty of the isolated strain by in-silico analysis of its draft genome.

\section{MATERIALS AND METHODS}

\subsection{Strain Characterization}

The purified strain from the activated dairy sludge was characterized as per standard protocol (Nandy et al., 2004). The Himedia antibiotic discs and the Himedia HiCarbohydrate TM Kit (KB009) were used for antibiotic sensitivity testing and substrate utilizing ability of the isolate as per manufacturer's protocol. The properties of the isolate were compared with that of Aeromonas sp. as reported by others (Agger et al., 1985; VanderKooij and Hijnen, 1988). Aeromonas sp. is known as a biofilm former (Lynch et al., 2002). The current strain under investigation was tested for biofilm formation as per standard method (Martin et al., 2008). The effect of water extract of Mentha spicata and essential oil of Ocimum sanctum on biofilm formation by the strain was studied following $18 \mathrm{~h}$. incubation.

\subsection{Production of Ammonia with the Reduction of Nitrate and Protein}

The experimental strain MCC 2167 was inoculated in Luria bertini broth overnight at $37^{\circ} \mathrm{C}$. Sweet shop effluent was inoculated with 1, 2, 4, 6 and $8 \%$ of overnight culture individually and maintained at $37^{\circ} \mathrm{C}$ under stationary condition for $18 \mathrm{~h}$. The quantitative analysis of ammonia production was done using Nesslerization as per the prescribed protocol of Central Pollution Control Board, India for water and waste water. Further to this, the percentage reduction of nitrate was calculated using the method of Cataldo et al. (1975) and that of protein using the Lowry method. The amount of ammonia produced was monitored at $18 \mathrm{~h}$. of growth at $37^{\circ} \mathrm{C}$. It was compared with the production of ammonia using modified Haber's process (Marnellos and Stoukides, 1998). 


\subsection{In-Silico Analysis}

All the contigs generated by the draft genome sequence were submitted to the Rapid Annotation using Subsystem Technology server (Aziz et al., 2008). Each contig of the draft genome were subjected to BLAST analysis. The percentage identity of the experimental strain with the type strain sequences in the data base was assessed and plotted as a pie chart. Similarity of draft genome sequence at the nucleotide level with that of Aeromonas sp. (closest neighbour as reported from BLAST analysis) was assessed using a similarity matrix, dot plot analysis through a genomic similarity search tool YASS (Noe and Kucherov, 2005). The inter-genomic distance between the two bacterial strains was also calculated using 2.0 version DSMZ Genome-To-Genome Distance calculator [https://www.dsmz.de/research/microorganisms/projects/ genome-to-genome-distance-calculator.html]. The genome rearrangement between the current strain and the closest neighbour (Aeromonas sp.) was investigated through MAUVE analysis. The pathway of nitrogen metabolism was referred using the Kyoto Encyclopedia of Genes and Genomes (KEGG) database; the putative genes for ammonia production were considered for emphasizing the genomic level variation in the chromosomal region between the experimental strain and its closest neighbour as conferred by RAST analysis.

\section{RESULTS}

\subsection{Strain Characterization}

Aeromonas shows optimum growth at $35^{\circ} \mathrm{C}$ (Hazen et al., 1978) while that for the current strain was at $37^{\circ} \mathrm{C}$. The former can utilize lactose, galactose, glycerol, inositol, mannitol, mannose, raffinose, xylose and rhamnose; the later cannot use these carbohydrates for growth. The latter is sensitive to Trimethoprim $(5 \mathrm{mcg})$ while no such report is available for the former to the best of our knowledge. The remaining qualities match in both the strains. The strain was a strong biofilm former (optical density 1.12 \pm 0.14 ) which was inhibited (29.61\%) with water extract of Mentha spicata. As per (Martin et al., 2008), optical density at $620 \mathrm{~nm}$ above 0.65 is considered as a strong biofilm former. Essential oils of Ocimum sanctum caused inhibition (27.87\%) of biofilm formation in the current strain under investigation as has been reported for Aeromonas hydrophila (Wan et al., 1998). The data was statistically validated using Microsoft Excel 2007 by two sample one tailed student t-test assuming equal variance at 5\% confidence level and found to be significant.

\subsection{Production of Ammonia with the Reduction of Nitrate and Protein}

MCC 2167 showed maximum production of ammonia (1194.33 $\mu \mathrm{g} / 100 \mathrm{~mL} / 18 \mathrm{~h}$.) (Fig. 1a) as well as highest removal of nitrate (35.52\%) (Fig. 1b) and protein $(81.67 \%)$ (Fig. 1c) upon inoculation with 6\% starter culture. The starting material was sweet shop effluent under static condition at $37^{\circ} \mathrm{C}$. The 1 st two parameters were interlinked as nitrate gets converted into ammonia. However, the reduction of protein was due to production of protease which was highest in case of 6\% (376.7 unit activity $/ \mathrm{ml} /$ hour $)$ as compared to $1 \%$ (289.5 unit activity $/ \mathrm{ml} /$ hour) and 8\% (284.3 unit activity/ml/hour) inoculums. Each experiment was repeated at least thrice. Statistical validation was performed using Microsoft Excel 2007 by two sample one tailed student t-test assuming equal variance at $5 \%$ confidence level. The analysis confirms significant ammonia production, nitrate as well as protein removal at all percentages of inoculum except for $1 \%$. The modified Haber's process (Marnellos and Stoukides, 1998) reports ammonia production of $10^{-9} \mathrm{moles} / \mathrm{sec}$ at atmospheric pressure and $570^{\circ} \mathrm{C}$ temperature. It was by far the most efficient ammonia producing method. Here we find ammonia production at $37^{\circ} \mathrm{C}$ under ambient pressure to the tune of $11 \times 10^{-9} \mathrm{moles} / \mathrm{sec}$. It is 11 times more efficient than the modified haber's process and much more economically viable as compared to the modified Haber's process which operates at about $570^{\circ} \mathrm{C}$.

\subsection{In-Silico Analysis}

The draft genome submitted to the RAST database generated a total of 4841753 assembled reads with 138 contigs. The $\mathrm{G}+\mathrm{C}$ content was reported to be $61.6 \%$. BLAST analysis of the 138 individual contigs (nucleotide level) of MCC 2167 revealed maximum identity with the genus Aeromonas hydrophila (Fig. 2a). Considering Aeromonas hydrophila strain as the nearest neighbour as per BLAST analysis, further insilico analysis was carried out with Aeromonas hydrophila subsp. hydrophila ATCC 7966 as the type strain. The genome sequence of Aeromonas hydrophila subsp. hydrophila ATCC 7966 was submitted to RAST server for its genome annotation with a single contig of 4744448 nucleotides. It reads a $\mathrm{G}+\mathrm{C}$ content of $61.5 \%$. 
Thungri Ghoshal et al. / OnLine Journal of Biological Sciences 14 (2): 70-83, 2014

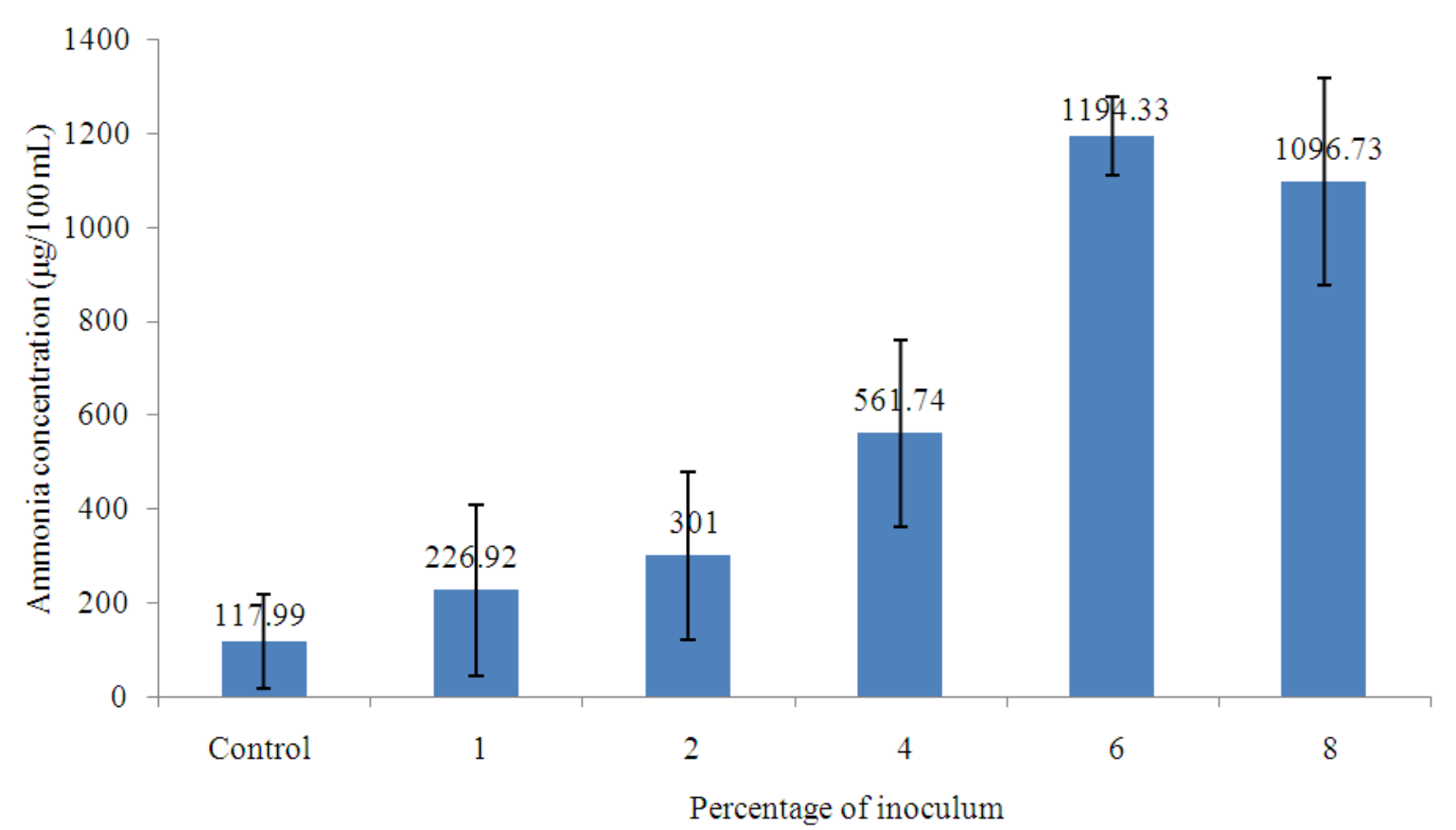

(a)

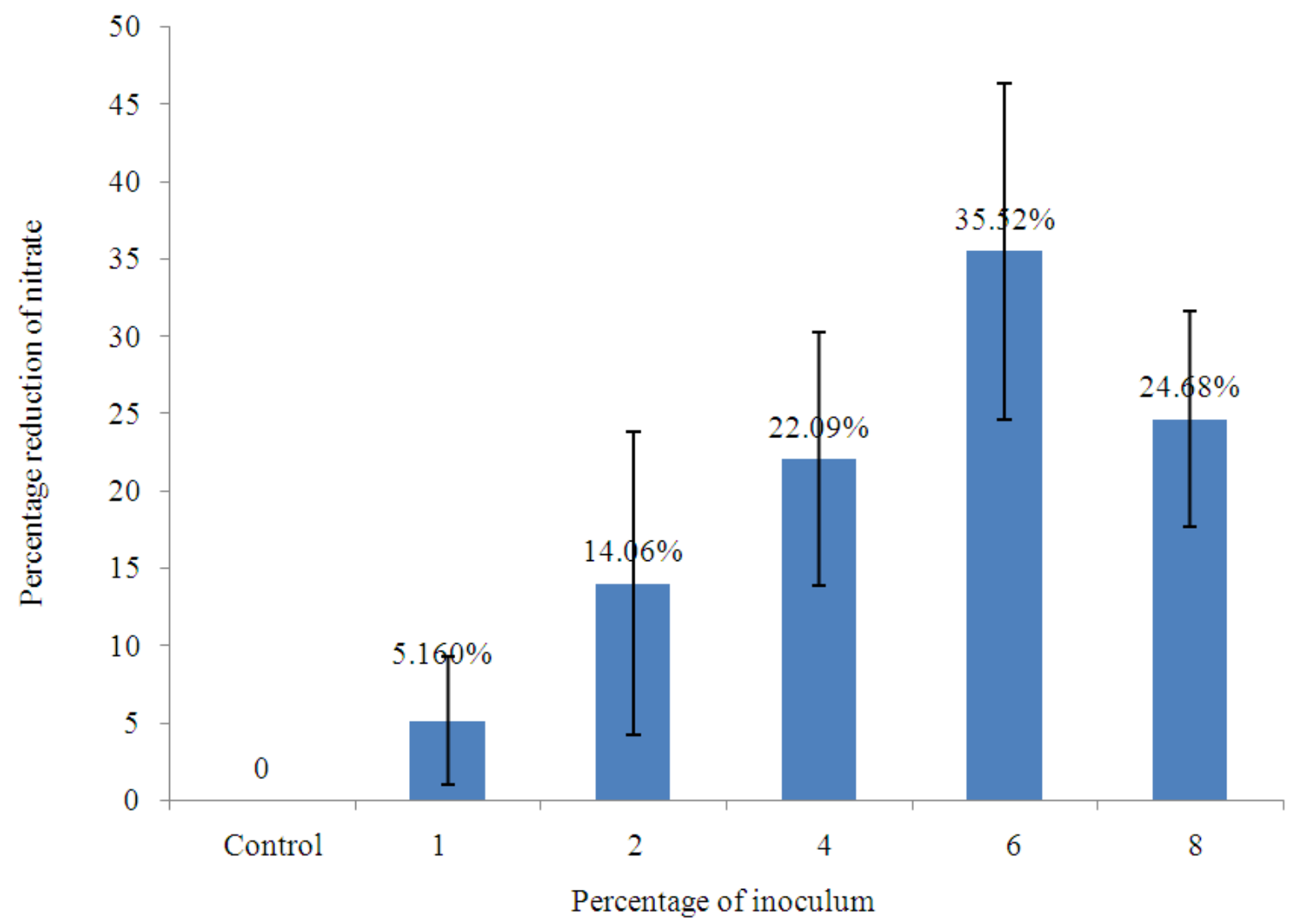

(b) 
Thungri Ghoshal et al. / OnLine Journal of Biological Sciences 14 (2): 70-83, 2014

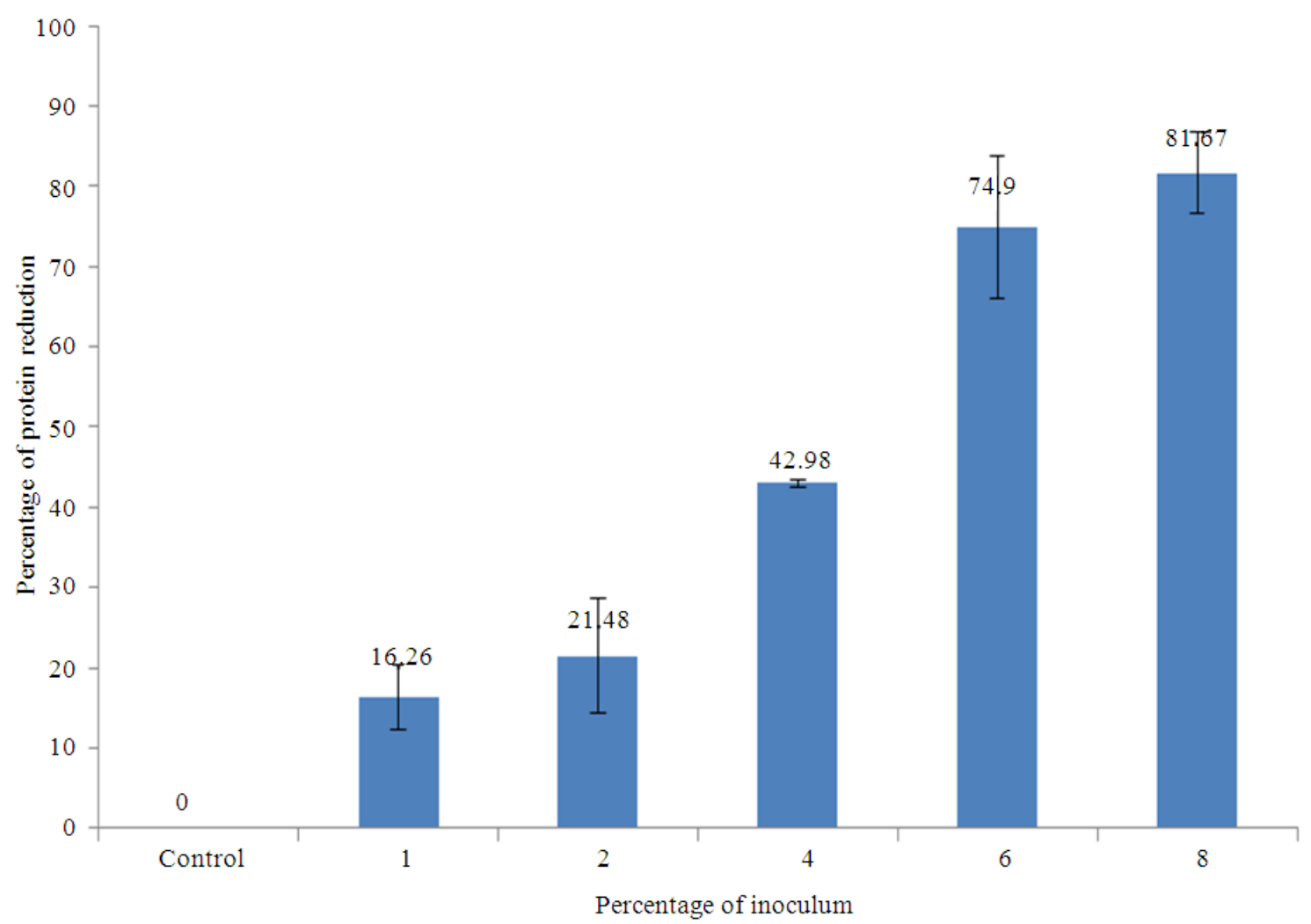

(c)

Fig. 1. The isolate was grown in sweet shop effluent under atmospheric pressure and $37^{\circ} \mathrm{C}$ for $18 \mathrm{~h}$. The effluent were inoculated with 1, 2, 4,6 and 8\% confluent overnight culture and the following were measured: (a) Extent of production of ammonia in $\mu \mathrm{g} / 100 \mathrm{~mL}$; (b) nitrate removal from the culture as percentage reduction; (c) protein removed from the culture as \% removal. At $6 \%$ there was highest production of ammonia and maximum conversion of nitrate. Here the later was converted to former. The protein removal was also highest at $6 \%$ inoculums due to higher production of protease by the isolate

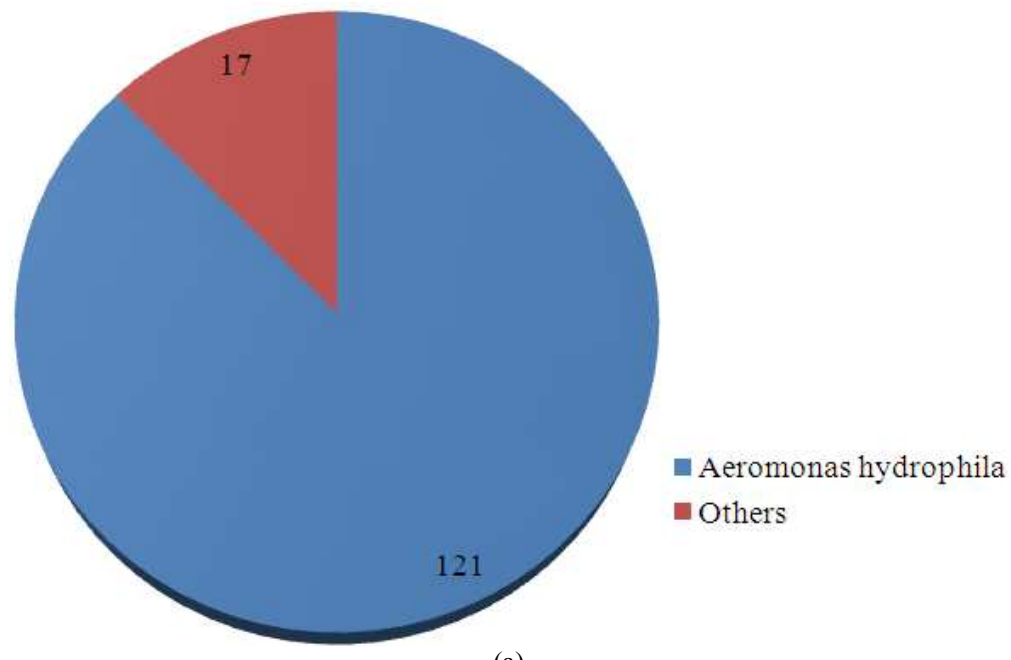

(a) 


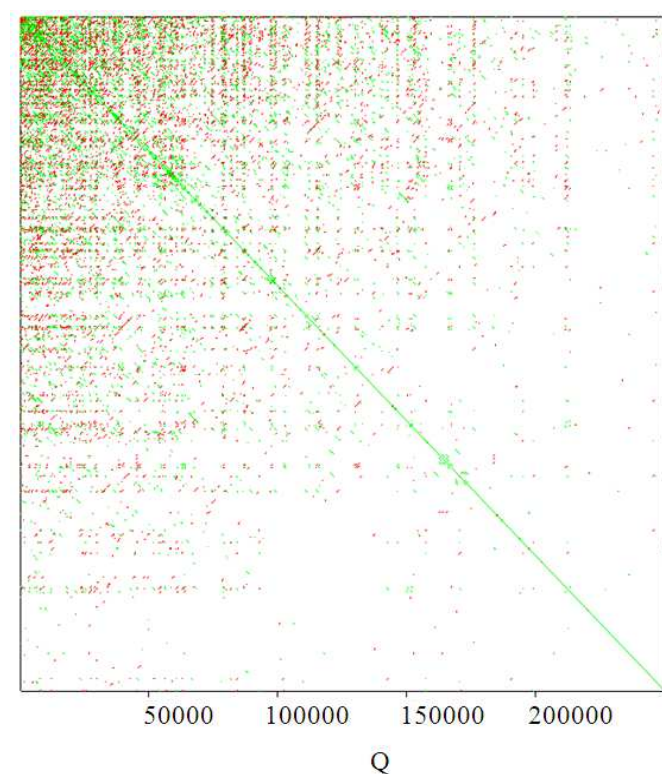

(b)

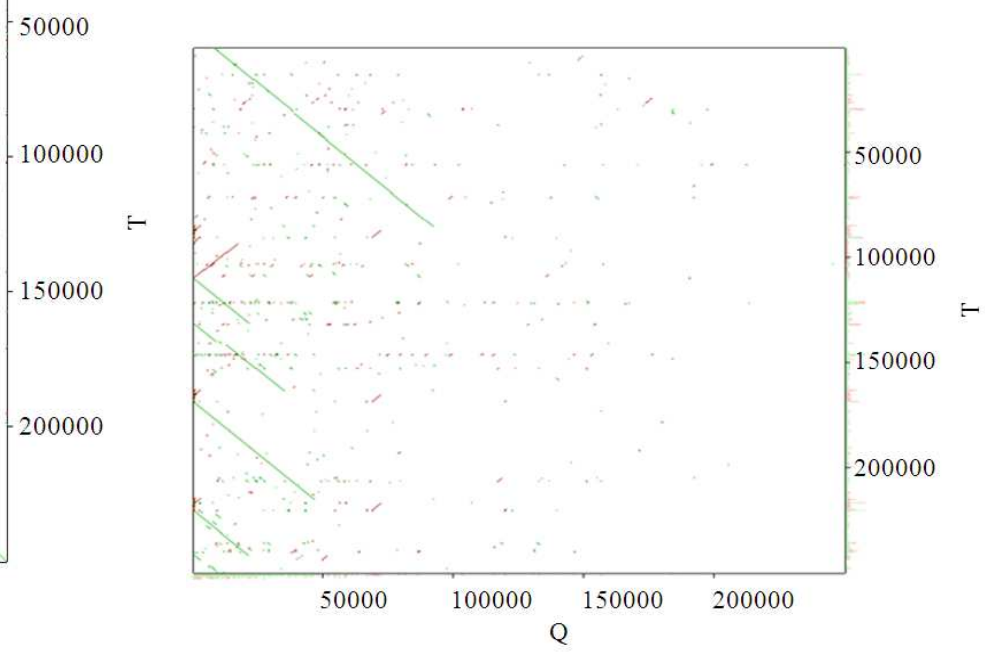

(c)

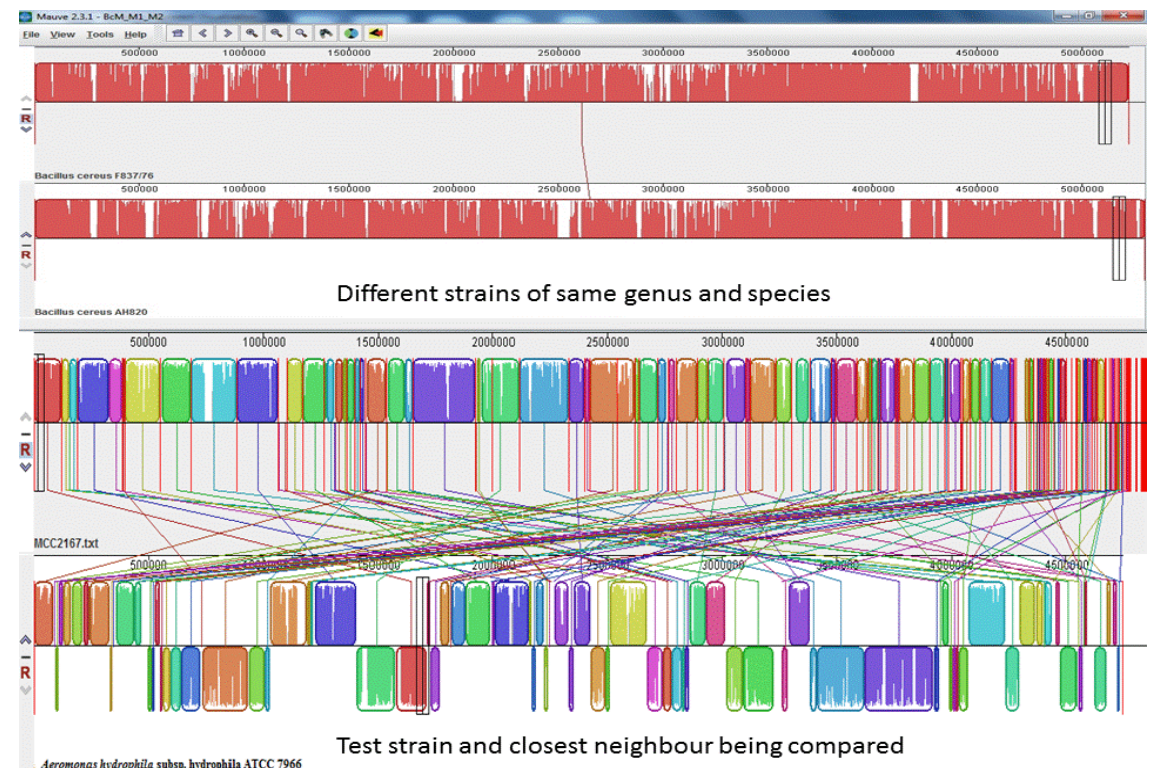

(d)

Fig 2: In-silico analysis of the draft genome of MCC 2167 as compared to Aeromonas hydrophila subsp. hydrophila ATCC 7966. (a) Blast analysis of (138) individual contigs of MCC 2167 representing maximum identity with Aeromonas hydrophila. (b) Dot plot alignment of related sequences depicting an ideal plot for identical/similar strains analyzed using YASS. (c)The dot plot alignment between MCC 2167 and Aeromonas hydrophila subsp. hydrophila ATCC 7966 representing frame shifts as well as inversion to the small stretch of similar nucleotide sequences analyzed using YASS Dot plot. (d) MAUVE based genome rearrangement of different strains of the same genus and species depicting conserved genomic sequence with no genomic rearrangement represented as local co-linear blocks on the top panel. MAUVE based genome analysis showing high genomic rearrangement within the two strains of MCC 2167 and Aeromonas hydrophila subsp. hydrophila ATCC 7966 pointing towards distinct difference in identity of the two organisms under consideration on the bottom panel 
In order to assess the similarity of the two sequences and identify the region of close similarity, dot plot analysis was conducted. Two identical sequences would appear as a straight line as represented in Fig. 2 b. However the current comparison of MCC 2167 with the type strain (Fig. 2c) represents a frame shift with inverted repeats for regions of similarity. The result points towards distinct difference between the two sequences used in this study. The conserved sequences of these two strains under investigation were further analyzed for genome rearrangement using MAUVE analysis. Different strains of same species show minimal rearrangement (Fig. 2d) while the current study shows extensive rearrangement of the genome (Fig. 2e). Thus the isolate MCC 2167 would be a different species from that of Aeromonas hydrophila subsp. hydrophila ATCC 7966.

Inter genomic distance between the two strains were analyzed using the DSMZ Genome to genome distance calculator. A percentage similarity of $\geq 70 \%$ between the 2 sequences is referred to as the same species. Depending on the genome length formula1 calculates the length of all High Scoring Sequence Pairs (HSP) per unit total length; formula 2 enumerates the sum of all the identities found by high scoring sequence pair per unit length of the total High Scoring sequence pairs while formula 3 calculates the sum of all identities found in HSPs divided by total genome length. Submitting the draft genome sequence of MCC 2167, formula 2, which is independent of the length of the genome sequence, is recommended compared to fomula 1 and 3 . The DNA DNA hybridisation estimate as per formula 1,2 and 3 were 85.20 $\pm 3.39, \quad 50.10 \pm 2.63$ and $79.90 \pm 3.22 \%$ respectively. The value obtained using formula 2 depicted variations in the comparing bacterial strains at the species level. This is in agreement with the dot plot as well as the MAUVE analysis.

Further, following the RAST annotation, the genome size of Aeromonas sp. MCC 2167 (4,841,753 bp) comprised of 4375 Coding DNA Sequences (CDS) with 29 RNAs according to its existing genomic database. The features of functionally related protein families form the subsystem feature of the RAST database. The draft genome comprises of $53 \%$ subsystem features (with total number of 2293 genes where 135 are hypothetical genes and 2158 are non- hypothetical genes) and 47\% non-subsystem feature (with total number of 2084 genes and 1008 hypothetical genes). The similar features of Aeromonas hydrophila subsp. hydrophila ATCC 7966 $(4,744,448$ bp) comprised of 4284 coding DNA sequences with 158 RNAs. Its draft genome comprised of $55 \%$ subsystem feature (Total number of gene-2316 while hypothetical genes-142) and $45 \%$ non-subsystem features (Total genes-1968, hypothetical genes-932). Table 1 enumerates the variation in the number of putative genes between MCC 2167 and that of Aeromonas hydrophila subsp. hydrophila ATCC 7966 within the functionally related protein families forming the subsystem. It reflects nearly $10 \%$ decrease in the number of genes involved in carbohydrate metabolism in case of MCC 2167. This could be responsible for its inability to utilize a wide range of substrates unlike the Aeromonas sp. It indicates that the strain under investigation cannot utilize major pathways of carbohydrate utilization and its principle energy expenditure is involved in production of ammonia. Comparing the functional parts of the two strains on the basis of presence of all the genes of an active variant in the RAST subsystem, 125 genes were found unique in MCC 2167 while 133 genes present in Aeromonas hydrophila subsp. hydrophila ATCC 7966 were absent in MCC 2167. Thus the two strains show significant differences among themselves.

\subsection{In-Silico Comparison of Metabolic Pathway}

The nitrogen metabolism with special emphasis on ammonia producing pathway was analysed in-silico using KEGG (Fig. 3). KEGG represents the reduction of nitrate to ammonia in a two-step reaction process similar to the dissimilatory nitrate reduction pathway. The putative genes represented by the Enzyme Commission numbers (EC no.) EC 1.7.99.4, EC 1.7.1.4 and EC 1.7.1.2 are referred to as periplasmic nitrate reductase precursor, nitrite reductase [NAD $(\mathrm{P}) \mathrm{H}]$ large and small subunit as well as cytochrome c552 precursor respectively. EC 1.7.99.4. marks the conversion of nitrate to nitrite by periplasmic nitrate reductase precursor. Further, for the conversion of nitrite to ammonia, the putative genes nitrite reductase [NAD (P)H] small subunit and large subunit are indicated as EC 1.7.1.4. in the KEGG pathway. 


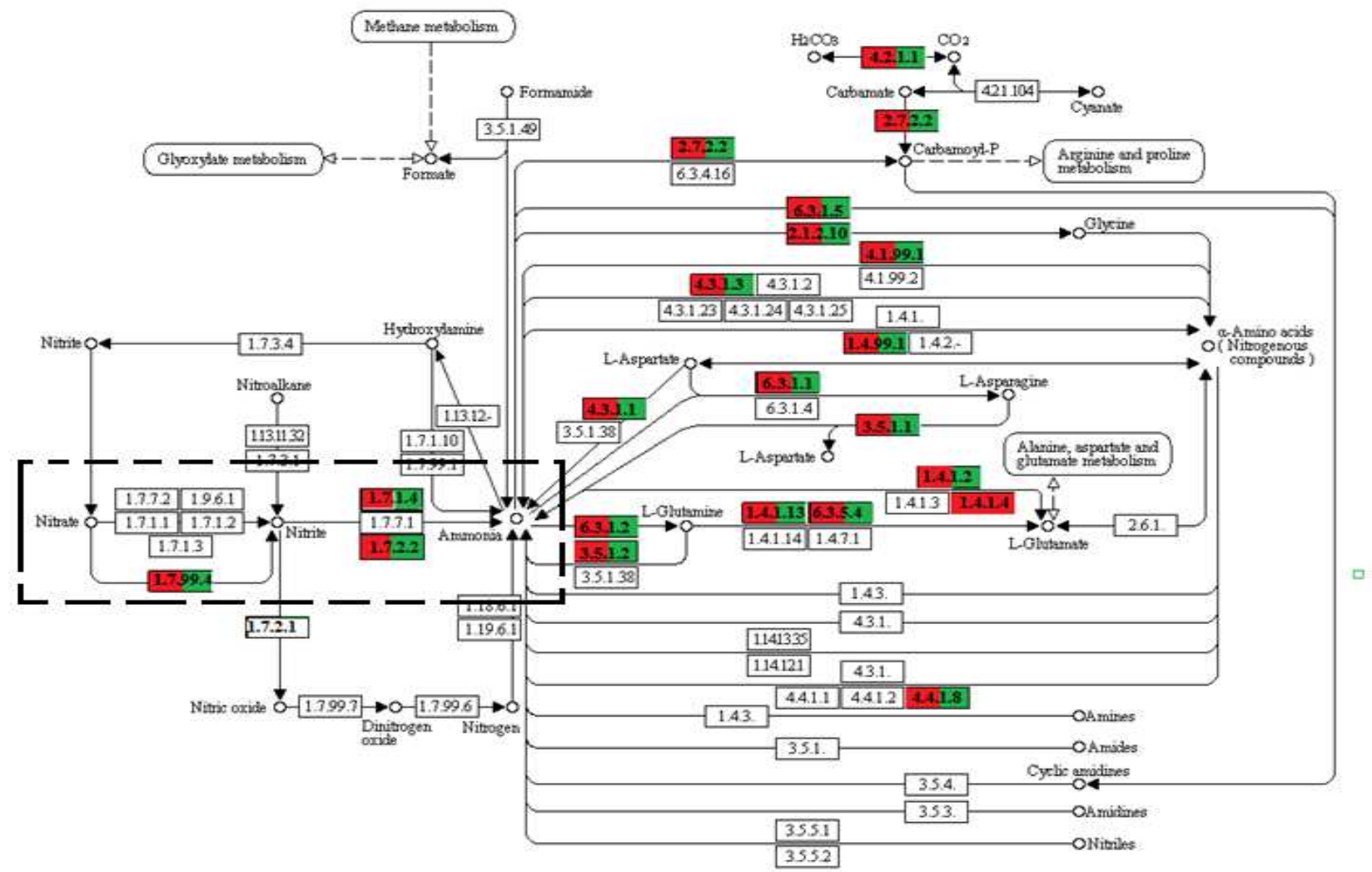

Fig. 3. KEGG pathway for Nitrogen Metabolism of MCC 2167 and its com-parison with the related similar organism Aeromonas hydrophila ATCC 7966 hydrophila (http://rast.nmpdr.org/seedviewer.cgi). The EC numbers marked in red and green are present in the strains under investigation

Nitrate is reduced to nitrite by nitrate reductase. In prokaryotes this enzyme is classified into three types namely assimilatory Nitrate reductases (Nas), Periplasmic Nitrate reductases (Nap) and respiratory Nitrate reductase (Nar). As per the RAST database, the comparison of MCC 2167 with other bacterial species, envisage the presence of Nap in the experimental strain for reducing nitrate to nitrite. The second step of conversion of nitrite to ammonia is catalysed by Cytochrome C552 (nrfA), the terminal reductase of the formate dependent pathway (Darwin et al., 1993).

The variation in the chromosomal region of the genes (Fig 4a-d) involved in ammonia production as per the KEGG-nitrogen metabolic pathway were compared (Table 2a-d) to distinguish between MCC 2167 with its four closest neighbours based on the presence/absence of a hypothetical/non-hypothetical gene in a given region or the location of the genome in the reverse/forward strand as annotated by RAST. The genes under investigation were coloured red. The results clearly show some variation in the chromosomal arrangement of genes between MCC 2167 and its closest neighbour Aeromonas hydrophila.

\section{DISCUSSION}

The in-silico analysis confirms MCC 2167 to be both similar and dissimilar with Aeromonas hydrophila in different aspects. Similar approach has been evident for understanding the genome of phosphate accumulating bacteria (Kawakoshi et al., 2012). The lack for genes for carbohydrate metabolism explains the failure of this strain to utilize many of the substrates that Aeromonas is capable of utilizing. 
Thungri Ghoshal et al. / OnLine Journal of Biological Sciences 14 (2): 70-83, 2014

Table 1. Comparison of the number of putative genes between MCC 2167 and Aeromonas hydrophila subsp. hydrophila ATCC 7966 within the functionally related protein families as annotated by the RAST database

\begin{tabular}{|c|c|c|}
\hline $\begin{array}{l}\text { Features of functionally } \\
\text { related protein family }\end{array}$ & $\begin{array}{l}\text { Feature counts } \\
\text { of Aeromonas hydrophila } \\
\text { subsp. ATCC } 7966\end{array}$ & $\begin{array}{l}\text { Feature counts } \\
\text { of MCC } 2167\end{array}$ \\
\hline Cofactors, vitamins, prosthetic groups, pigments & 293 & 255 \\
\hline Cell wall and capsule & 191 & 199 \\
\hline Virulence, disease and defense & 96 & 91 \\
\hline Potassium metabolism & 39 & 32 \\
\hline Photosynthesis & 0 & 0 \\
\hline Miscellaneous & 27 & 27 \\
\hline Phages, prophages, transposable elements, plasmids & 3 & 7 \\
\hline Membrane transport & 201 & 183 \\
\hline Iron acquisition and metabolism & 52 & 33 \\
\hline RNA metabolism & 221 & 224 \\
\hline Nucleosides and nucleotides & 126 & 124 \\
\hline Protein metabolism & 273 & 238 \\
\hline Cell division and cell cycle & 43 & 42 \\
\hline Motility and chemotaxis & 131 & 126 \\
\hline Regulation and cell signaling & 99 & 87 \\
\hline Secondary metabolism & 6 & 6 \\
\hline DNA metabolism & 112 & 159 \\
\hline Regulons & 9 & 4 \\
\hline Fatty acids, lipids and isoprenoids & 139 & 139 \\
\hline Nitrogen metabolism & 45 & 39 \\
\hline Dormancy and sporulation & 2 & 5 \\
\hline Respiration & 172 & 164 \\
\hline Stress response & 151 & 145 \\
\hline Metabolism of aromatic compounds & 11 & 11 \\
\hline Amino acids and derivatives & 425 & 454 \\
\hline Sulfur metabolism & 42 & 43 \\
\hline Phosphorus metabolism & 44 & 43 \\
\hline Carbohydrates & 465 & 42 \\
\hline
\end{tabular}

Table 2a. Variation in the genomic region of the focus gene (represented 1 in Fig 4a) periplasmic nitrate reductase precursor (EC 1.7.99.4) of MCC 2167 compared to four similar related strains-Aeromonas hydrophila subsp. hydrophila ATCC 7966, Aeromonas salmonicida subsp. salmonicida A449, Psychromonas ingrahami ingrahamii 37, Psychromonas sp. CNPT3

\begin{tabular}{|c|c|c|c|c|}
\hline Variation & Set no. & Function & $\begin{array}{l}\text { No. of base pair } \\
\text { and amino acid }\end{array}$ & $\begin{array}{l}\text { Comparison with } \\
\text { similar organism }\end{array}$ \\
\hline $\begin{array}{l}\text { Reverse } \\
\text { orientation }\end{array}$ & 11 & $\begin{array}{l}\text { Molybdenum transport } \\
\text { ATP binding protein } \\
\text { ModC }\end{array}$ & 1077bp; 359aa & $\begin{array}{l}\text { Reverse orientation is also in Aeromonas } \\
\text { hydrophila subsp. } \\
\text { hydrophila ATCC } 7966 \text { while has forward } \\
\text { orientation in the other organisms }\end{array}$ \\
\hline $\begin{array}{l}\text { Forward } \\
\text { orientation }\end{array}$ & 10 & $\begin{array}{l}\text { Molybdenum transport } \\
\text { system permease protein } \\
\text { ModB }\end{array}$ & $711 \mathrm{bp} ; 237 \mathrm{aa}$ & $\begin{array}{l}\text { The forward orientation is also } \\
\text { in Aeromonas hydrophila subsp. hydrophila } \\
\text { ATCC } 7966 \text { and have reverse orientation in } \\
\text { the other organisms }\end{array}$ \\
\hline $\begin{array}{l}\text { Deficient } \\
\text { gene }\end{array}$ & 23 & $\begin{array}{l}\text { Sensor histidine kinase/ } \\
\text { response regulator }\end{array}$ & 2097bp, 699aa & $\begin{array}{l}\text { Present in Aeromonas hydrophila subsp. } \\
\text { hydrophila ATCC } 7966 \text {, Aeromonas } \\
\text { salmonicida subsp. salmonicida A449 while } \\
\text { absent in MCC } 2167\end{array}$ \\
\hline Extra gene & 14 & $\begin{array}{l}\text { Periplasmic nitrate } \\
\text { Reductase component NapD }\end{array}$ & 297bp, 99aa & $\begin{array}{l}\text { Represented as "periplasmic di-heme c-type } \\
\text { cytochrome NapB" }\end{array}$ \\
\hline
\end{tabular}


Thungri Ghoshal et al. / OnLine Journal of Biological Sciences 14 (2): 70-83, 2014

Table 2b. Variation in the genomic region of nitrite reductase [NAD(P)H] small subunit (EC 1.7.1.4) between MCC 2167 as compared to four related organisms namely aeromonas hydrophila subsp. hydrophila ATCC 7966, Aeromonas salmonicida subsp. salmonicida A449, salmonella paratyphi, photobacterium profundum SS9

\begin{tabular}{|c|c|c|c|c|}
\hline Variation & Set no. & Function & $\begin{array}{l}\text { No. of base pair } \\
\text { and amino acid }\end{array}$ & $\begin{array}{l}\text { Comparison with similar } \\
\text { organism }\end{array}$ \\
\hline \multirow[t]{4}{*}{$\begin{array}{l}\text { Reverse } \\
\text { strand }\end{array}$} & 10 & ATP dependent protease $\mathrm{HslV}$ & 534bp; 178aa & $\begin{array}{l}\text { Sets } 10,9,4 \text { and } 1 \text { are present in the } \\
\text { forward strand of Aeromonas hydrophila } \\
\text { subsp. hydrophila ATCC } 7966\end{array}$ \\
\hline & 9 & $\begin{array}{l}\text { ATP dependent Hsl protease ATP } \\
\text { binding subunit HslU }\end{array}$ & $1329 b p, 443 a a$ & \\
\hline & 4 & $\begin{array}{l}\text { Nitrite reductase }[\mathrm{NAD}(\mathrm{P}) \mathrm{H}] \text { large } \\
\text { Subunit (EC 1.7.1.4) }\end{array}$ & $1188 \mathrm{bp}, 396 \mathrm{aa}$ & \\
\hline & $\begin{array}{l}1 \text { (focus } \\
\text { gene) }\end{array}$ & $\begin{array}{l}\text { Nitrite reductase }[\mathrm{NAD}(\mathrm{P}) \mathrm{H}] \text { small } \\
\text { subunit }(\mathrm{EC} \text { 1.7.1.4) }\end{array}$ & $318 b p ; 106 a a$ & \\
\hline $\begin{array}{l}\text { Forward } \\
\text { strand }\end{array}$ & $\begin{array}{l}\text { between } \\
\text { sets } 4 \text { and } 1\end{array}$ & Hypothetical protein & $114 \mathrm{bp} ; 38 \mathrm{aa}$ & $\begin{array}{l}\text { The hypothetical protein is present in the } \\
\text { reverse strand in Aeromonas hydrophila } \\
\text { sub. hydrophila ATCC } 7966 \text { and } \\
\text { Aeromonas salmonicida subsp. } \\
\text { salmonicida A449 }\end{array}$ \\
\hline \multirow{5}{*}{$\begin{array}{l}\text { Extra } \\
\text { protein } \\
\text { deficient }\end{array}$} & $\begin{array}{l}\text { Between sets } \\
10 \text { and } 9\end{array}$ & Hypothetical protein & $141 \mathrm{bp} ; 47 \mathrm{aa}$ & Absent in the other similar strains \\
\hline & 12 & Ribonuclease E inhibitor RraA & $609 b p, 203 a a$ & $\begin{array}{l}\text { Absent in the test strain while present in } \\
\text { Aeromonas hydrophila subsp. Hydrophila } \\
\text { ATCC7966 and Aeromonas salmonicida } \\
\text { subsp. salmonicida A449 }\end{array}$ \\
\hline & 13 & Putative preQ0 transporter & $675 \mathrm{bp}, 225 \mathrm{aa}$ & \\
\hline & 14 & aminopeptidaseN & $324 b p, 108 a a$ & \\
\hline & 16 & $\begin{array}{l}\text { Selenoprotein } \mathrm{O} \text { and cysteine } \\
\text { containing homologs }\end{array}$ & $1428 \mathrm{bp}, 476 \mathrm{aa}$ & \\
\hline
\end{tabular}

Table 2c. Variation in the genomic region of Nitrite reductase [NAD(P)H] large subunit (EC 1.7.1.4) of MCC 2167 as compared with four related species Aeromonas hydrophila subsp. hydrophila ATCC 7966, Aeromonas salmonicida subsp. salmonicida A449, Anopheles gambiae str. PEST, Vibrio vulnificus YJ016

\begin{tabular}{|c|c|c|c|c|}
\hline Variation & Set no. & Function & $\begin{array}{l}\text { No. of base pair } \\
\text { and amino acid }\end{array}$ & $\begin{array}{l}\text { Comparison with similar } \\
\text { organism }\end{array}$ \\
\hline \multirow[t]{5}{*}{$\begin{array}{l}\text { Reverse } \\
\text { orientation }\end{array}$} & 1 (focus gene) & $\begin{array}{l}\text { Nitrite reductase }[\mathrm{NAD}(\mathrm{P}) \mathrm{H}] \text { large } \\
\text { subunit (EC 1.7.1.4) }\end{array}$ & 2523bp;841aa & $\begin{array}{l}\text { Sets } 1,10,8 \text {,and } 2 \text { are present in the } \\
\text { forward strand of Aeromonas hydrophila } \\
\text { subsp. hydrophila ATCC } 7966\end{array}$ \\
\hline & 10 & ATP dependent protease HslV & $534 \mathrm{bp} ; 178 \mathrm{aa}$ & \\
\hline & 8 & $\begin{array}{l}\text { ATP dependent Hsl protease ATP } \\
\text { binding subunit HslU }\end{array}$ & $1329 b p ; 443 a a$ & \\
\hline & 2 & $\begin{array}{l}\text { Nitrite reductase }[\mathrm{NAD}(\mathrm{P}) \mathrm{H}] \text { small } \\
\text { subunit }(\mathrm{EC} \text { 1.7.1.4) }\end{array}$ & 318bp;106aa & \\
\hline & $\begin{array}{l}\text { Between } \\
\text { sets } 1 \text { and } 2\end{array}$ & Hypothetical protein & $114 \mathrm{bp} ; 38 \mathrm{aa}$ & \\
\hline Extra & $\begin{array}{l}\text { Between } \\
\text { sets } 11 \text { and } 7\end{array}$ & Hypothetical protein & $141 \mathrm{bp} ; 47 \mathrm{aa}$ & Absent in all the other 4 similar strains protein \\
\hline $\begin{array}{l}\text { Deficient } \\
\text { protein }\end{array}$ & 13 & Ribonuclease E inhibitor RraA & $609 b p, 203 a a$ & $\begin{array}{l}\text { Absent in the test strain and Anopheles } \\
\text { gambiae str. PEST } \\
\text { Vibrio vulnificus YJ016 } \\
\text { Present in Aeromonas hydrophila subsp. } \\
\text { hydrophila ATCC } 7966 \\
\text { Aeromonas salmonicida subsp. salmonicida A449 }\end{array}$ \\
\hline
\end{tabular}


Thungri Ghoshal et al. / OnLine Journal of Biological Sciences 14 (2): 70-83, 2014

Table 2d. Variation in the genomic region of the focus gene Cytochrome c552 precursor (EC 1.7.2.2) (1829) of MCC 2167 compared with four related species Aeromonas hydrophila subsp. hydrophila ATCC 7966, Aeromonas salmonicida subsp. salmonicida A449, Anopheles gambiae str. PEST, Vibrio vulnificus YJ016

\begin{tabular}{|c|c|c|c|c|}
\hline Variation & Set no. & Function & $\begin{array}{l}\text { No. of base pair } \\
\text { and amino acid }\end{array}$ & $\begin{array}{l}\text { Comparison with similar } \\
\text { organism }\end{array}$ \\
\hline \multirow[t]{3}{*}{$\begin{array}{l}\text { Reverse } \\
\text { orientation }\end{array}$} & 3 & Nrf D protein & 957bp; 319aa & $\begin{array}{l}\text { Sets } 3,4 \text { and } 7 \text { are present in the forward } \\
\text { strand of Aeromonas hydrophila subsp. } \\
\text { hydrophila ATCC } 7966\end{array}$ \\
\hline & 7 & $\begin{array}{l}\text { Cytochrome c-type heme lyase } \\
\text { subunit nrfE, nitrite reductase } \\
\text { compex assembly }\end{array}$ & $1962 b p, 654 a a$ & \\
\hline & 4 & $\begin{array}{l}\text { Cytochrome c-type heme lyase } \\
\text { subunit nrfG, nitrite reductase } \\
\text { compex assembly }\end{array}$ & 1188bp, 396aa & \\
\hline \multirow{3}{*}{$\begin{array}{l}\text { Forward } \\
\text { Orientation }\end{array}$} & 5 & Nrf C protein & $618 \mathrm{bp}, 206 \mathrm{aa}$ & Present in the reverse strand in \\
\hline & & & & $\begin{array}{l}\text { Aeromonas hydrophila subsp. hydrophila } \\
\text { ATCC 7966, Aeromonas salmonicida } \\
\text { subsp. salmonicida A } 449 \text { and in the } \\
\text { forward strand of the test strain MCC } 2167 .\end{array}$ \\
\hline & 8 & $\begin{array}{l}\text { Putative thiol disulphide } \\
\text { oxidoreductase; nitrite reductase } \\
\text { complex assembly }\end{array}$ & $588 \mathrm{bp}, 196 \mathrm{aa}$ & \\
\hline $\begin{array}{l}\text { Extra } \\
\text { protein }\end{array}$ & $\begin{array}{l}\text { Between } \\
\text { set } 14 \text { and } 13\end{array}$ & Hypothetical protein & 120bp; 40aa & Absent in the other similar organisms. \\
\hline
\end{tabular}

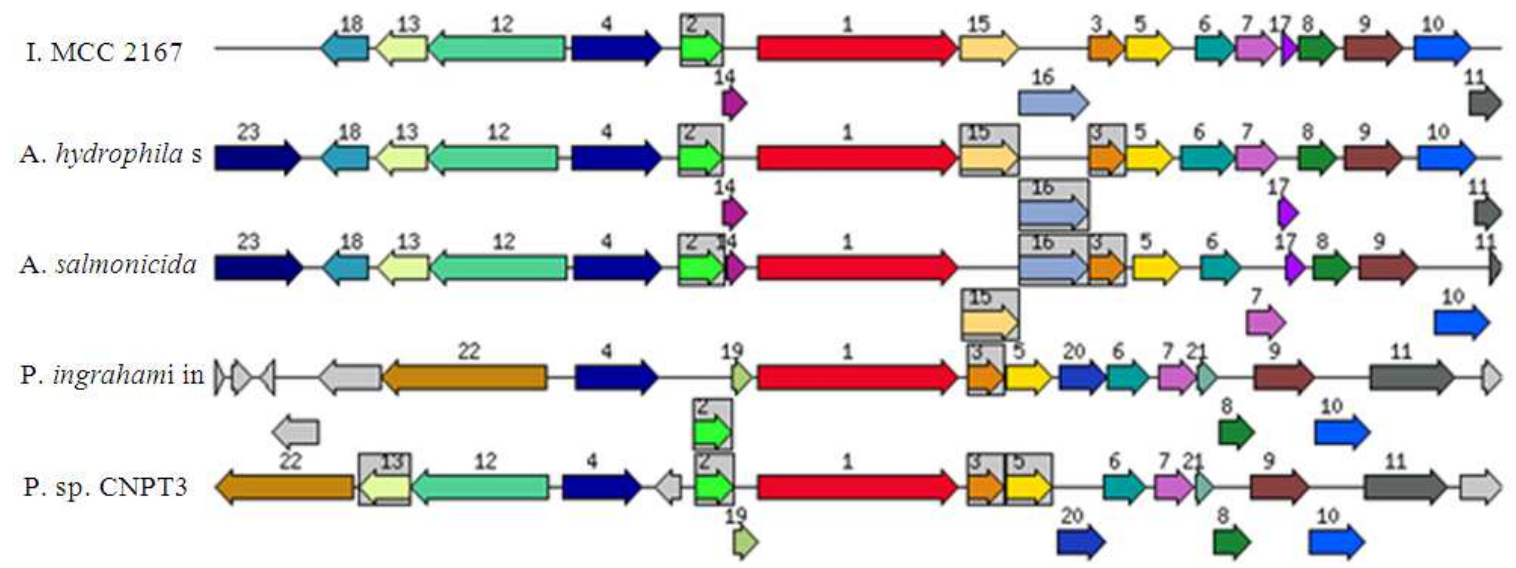

(a)

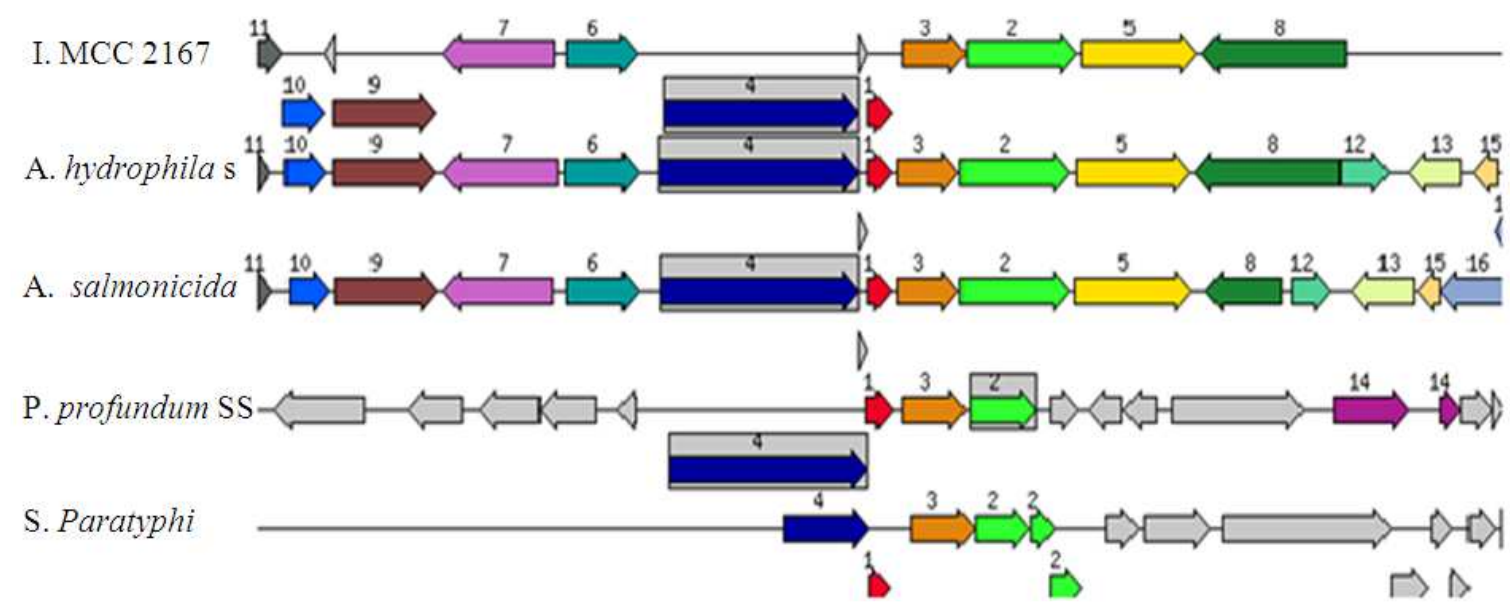

(b) 


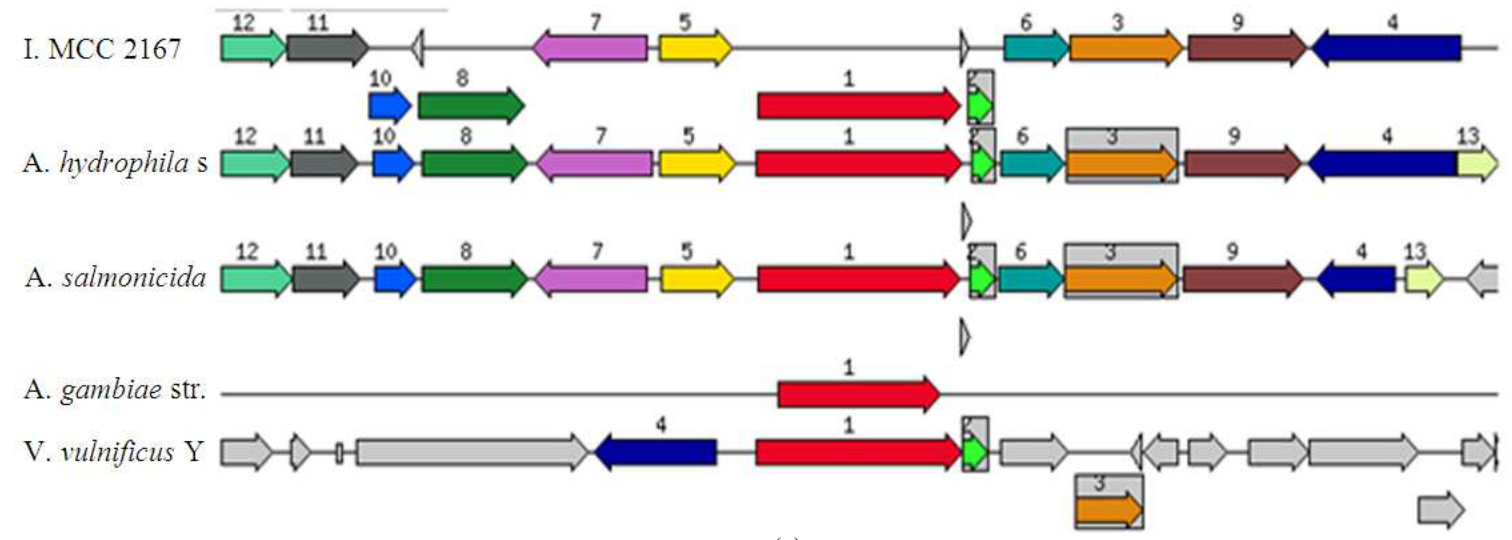

(c)

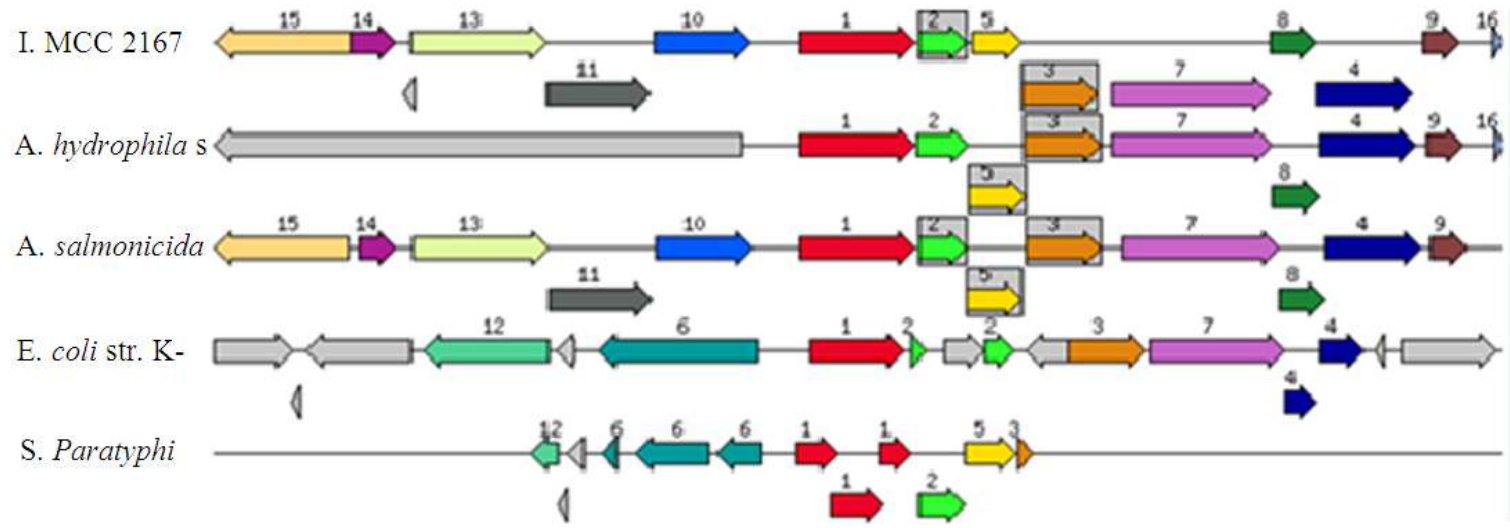

(d)

Fig. 4. Variation in selected genomic region of MCC 2167 were studied for 4a. periplasmic nitrate reductase precursor (EC 1.7.99.4) in comparison with four related strains Aeromonas hydrophila subsp. hydrophila ATCC 7966, Aeromonas salmonicida subsp. salmonicida A449, Psychromonas ingrahami ingrahamii 37, Psychromonas sp. CNPT3; 4b. Nitrite reductase [NAD(P)H] small subunit (EC 1.7.1.4) in comparison with four closely related organisms namely strains Aeromonas hydrophila subsp. hydrophila ATCC 7966, Aeromonas salmonicida subsp. salmonicida A449, Salmonella paratyphi, Photobacterium profundum SS9; 4c. Nitrite reductase [NAD(P)H] large subunit (EC 1.7.1.4) of MCC 2167 as compared with four related species Aeromonas hydrophila subsp. hydrophila ATCC 7966, Aeromonas salmonicida subsp. salmonicida A449, Anopheles gambiae str. PEST, Vibrio vulnificus YJ016; 4d. Cytochrome c552 precursor (EC 1.7.2.2) (1829) of MCC 2167 compared with four related species Aeromonas hydrophila subsp. hydrophila ATCC 7966, Aeromonas salmonicida subsp. salmonicida A449, Anopheles gambiae str. PEST, Vibrio vulnificus YJ016

The ammonia production result reflects this process as the most efficient system for ammonia production where a waste product is converted into a by-product with immense industrial application in an economically viable process.

\section{CONCLUSION}

This study reports efficient production of ammonia from dairy effluent by the strain MCC 2167 thus converting a waste product into a commercially viable by-product. The strain shows immense similarity with Aeromonas hydrophila but certain distinct differences at the metabolic level in terms of substrate utilization. The variation was reconfirmed using in-silico analysis. This combined approach of conventional taxonomic method and bioinformatic analysis of the draft genome of the organism points towards MCC 2167 to be a different species of genus Aeromonas with 11 times more ammonia producing ability under ambient pressure and $37^{\circ} \mathrm{C}$ temperature. Being a strong biofilm former, the bioconversion could be 
performed in a biofilm based packed bed reactor to make the process sustainable. Its application at the industrial level would lead to revenue generation during waste treatment in dairy industry, making effluent treatment and overall process sustainable. The similar approach could also be used for local sweet shop effluent treatment however this in-silico approach could only be used in case of availability of draft/whole genome sequence. The microbial formulation could be used in future to develop small prototypes for installation at local sweet shops/factories in addition to dairy industries for treatment of effluent. This would lead to detoxification of waste while generating revenue in terms of ammonia.

\section{ACKNOWLEDGEMENT}

The researchers would like to acknowledge the financial assistance of Department of Atomic Energy under the BRNS scheme; Indian Council of Agricultural Research under the NFBSFARA scheme and Department of Science and Technology, Government of India under the DST Inspire scheme for student scholarship; thank West Bengal University of Technology for the computational facility.

\section{REFERENCES}

Agger, W.A., J.D. McCornick and M.J. Gurwith, 1985. Clinical and microbiological features of Aeromonas hydrophila associated Diarrhea. J. Clin. Microbiol., 21: 909-913.

Aziz, R.K., D. Bartels, A.A. Best, M. DeJongh and T. Disz et al., 2008. The RAST server: Rapid annotations using subsystems technology. BMC Genom., 9: 75-75. DOI: 10.1186/1471-2164-9-75

Bhadouria, B.S. and V.S. Sai, 2011. Utilization and treatment of dairy effluent through biogas generation-a case study. Int. J. Environ. Sci., 1: 1621-1630. DOI: 10.6088/ijessi.00107020021

Carvalho, F., A.R. Prazeres and J. Rivas, 2013. Cheese whey wastewater-Characterization and treatment. Sci. Total Environ., 445-446: 385-396. DOI: 10.1016/j.scitotenv.2012.12.038

Cataldo, D.A., M. Maroon, L.E. Schrader and V.L. Youngs, 1975. Rapid colorimetric determination of nitrate in plant tissue by nitration of salicylic acid. Commun. Soil Sci. Plant Anal., 6: 71-80. DOI: $10.1080 / 00103627509366547$
Cota-Navarro, C.B., J. Carrillo-Reyes, G. DavilaVazquez, F. Alatriste-Mondragón and E. RazoFlores, 2011. Continuous hydrogen and methane production in a two-stage cheese whey fermentation system. Water Sci. Technol., 64: 367-374. DOI: 10.1021/ie071622x

Darwin, A., H. Hussai, L. Griffiths, J. Grove and Y. Sambongi et al., 1993. Regulation and sequence of the structural gene for cytochrome c552 from Escherichia coli: Not a hexahaem but a 50 kDatetrahaem nitrite reductase. Molecular Microbiol., 9: 1255-1265. DOI: 10.1111/j.13652958.1993.tb01255.x

Ertl, G., 1983. Primary steps in catalytic synthesis of ammonia. J. Vaccum Sci. Technol., 1: 1247-1247. DOI: $10.1116 / 1.572299$

Hazen, TC, C.B. Filmans, R.P. Hirsch and G.W. Esch, 1978. Prevalance and distribution of aeromonas hydrophila in United States. Applied Environ. Microbiol., 36: 731-738.

Kawakoshi, A., H. Nakazawa, J. Fukada, M. Sasagawa and Y. Katano et al., 2012. Deciphering the Genome of Polyphosphate Accumulating Actinobacterium Microlunatus phosphovorus. DNA Res., 19: 383394. DOI: $10.1093 /$ dnares/dss020

Lynch, M.J., S. Swift, D.F. Kirke, C.W. Keevil and C.E. Dodd et al., 2002. Biofilm: The regulation of biofilm development by quorum sensing in Aeromonas hydrophila. Environ. Microbiol., 4: 1828. DOI: 10.1046/j.1462-2920.2002.00264.x

Maghsoodi, V., A. Samadi and G. Zahara, 2007. Biodegradation of effluents from dairy plants by bacterial isolates. Iran. J. Chem. Chem. Eng., 26: 55-59.

Marnellos, G. and M. Stoukides, 1998. Ammonia synthesis at atmospheric pressure. Science, 282: 98100. DOI: $10.1126 /$ science.282.5386.98

Martin, R., N. Soberon, M. Vaneechoutte, A.B. Florez and F. Vazquez et al., 2008. Characterization of indigenous vaginal lactobacillus from women as probiotic candidates. Int. Microbiol., 11: 261-266. DOI: $10.2436 / 20.1501 .01 .70$

Najafpour, G.D., B.A. Hashemiyeh and M.B. Asadi, 2008. Biological treatment of dairy waste water in an upflow anaerobic sludge fixed film bioreactor. Am. Eur. J. Agric. Environ. Sci., 4: 251-257.

Nandy, P., A.R. Thakur and S. RayChaudhuri, 2004. Characterization of bacterial strains isolated through microbial profiling of urine samples. Online J. Biol. Sci., 71: 44-51. DOI: 10.3844/ojbsci.2007.44.51 
Noe, L. and G. Kucherov, 2005. YASS: Enhancing the sensitivity of DNA similarity search. Nucleic Acids Res., 33: W540-W543. DOI: 10.1093/nar/gki478

Patel, C. and D. Madamwar, 1996. Biomethanation of a mixture of salty cheese whey and poultry waste or cattle dung. Applied Biochem. Biotechnol., 60: 159166. DOI: $10.1007 / \mathrm{BF} 02788070$

Egner, S. and A. Karos, 2013. Purifying dairy waste water"-at the same time producing electricity.

RayChaudhuri, S., A. Saha, T. Ghoshal and A.R. Thakur, 2013. Draft genome sequence of ammonia-producing aeromonas sp. mds8 strain mcc2167 from sludge of a dairy effluent treatment plant. Genome. Announc., 1: E00710-713. DOI: 10.1128/genomeA.00710-13

Russell, J.B., H.J. Strobel and G.J. Chen, 1988. Enrichment and isolation of a ruminal bacterium with a very highspecific activity of ammonia production. Applied Environ. Microbiol., 54: 872877. DOI: 10.1128/AEM.68.10.4925-4931.2002
Schauernheim, D., 2006. “Ammonia” Ullmann's Encyclopedia of Industrial Chemistry Wiley-VCH.

Shanmugamand, K.T. and R.C. Valentine, 1975. Microbial production of ammonium ion from nitrogen. Proc. Nat. Acad. Sci. USA., 72: 136-139. DOI: $10.1073 /$ pnas.72.1.136

VanderKooij, D. and W.A. Hijnen, 1988. Nutritional versatility and growth kinetics of an Aeromonas hydrophila strain isolated from drinking water. Applied Environ. Microbiol., 54: 2842-2851. DOI: 10.1128/AEM.00372-11

Wan, J., A. Wilcock and M.J. Coventry, 1998. The effect of essential oils of basil on the growth of Aeromonas hydrophila and Pseudomonas fluorescens. J. Applied Microbiol., 84: 152-158. DOI: 10.1046/j.1365-2672.1998.00338.x 